\title{
Parental Attitude and Teacher Behaviours in Predicting School Bullying
}

\author{
M. Yüksel Erdoğdu \\ Correspondence: M. Yüksel Erdoğdu, PhD, Faculty of Education, İstanbul Sabahattin Zaim University, İstanbul, 34303, \\ Turkey.
}

Received: February 14, 2016 Accepted: February 27, $2016 \quad$ Online Published: March 14, 2016

doi:10.11114/jets.v4i6.1459

URL: http://dx.doi.org/10.11114/jets.v4i6.1459

\begin{abstract}
The main goal of this research is to present the relationship between "parental attitude and teacher behaviors in predicting school bullying". The population of this research is consisted of all primary school $4^{\text {th }}$ grade students within İstanbul Küçükçekmece Municipality borders. Data were gathered from lower, mid and upper socio-economic level schools ( 2 schools on each level, 6 schools in total.) 702 volunteer students constitute the sample of this research. 363 $(52 \%)$ of these students are female students and $338(48 \%)$ of the students are male students. Tendency for Bullying Scale, Parental Attitude Scale, Perceived Teacher Behavior Scale and an information form which was developed by the researcher were used in collecting data. T-test, one way analysis of variance (ANOVA) and multiple regression analysis were used in data analysis. Female students who do not attend cultural activities and who have low success levels have a higher bullying tendency. As students' ages increase, bullying tendency increases, too. Authoritarian behaviors of teachers, mothers and fathers (respectively) are the main predictors of bullying. Students who cannot have emotional sharing, who like to use force and who reflect negatively about events have a higher bullying tendency. Positive attitudes of teachers especially and their efforts to develop empathy skills in students are thought to be important in decreasing school bullying.
\end{abstract}

Keywords: bullying, parental attitude, teacher behavior

\section{Introduction}

Though there is a lot of research on aggression and the definition of aggression in literature, bullying is a newly examined topic. The main reason to this is thought to be because the term bullying has been defined recently compared to aggression and because bullying is studied under the title of aggression. According to the studies, the term bullying was used by Olweus in 1970s. Olweus drew attention to bullying in his research in Scandinavian countries in 1970s and 1980s (Olweus, 1973; 1978). The first study on school bullying was done by Heinemann in Sweden in 1972 (Wolke, Woods, Stanford and Schulz, 2001).

According to Olweus (1973), bullying means "one or more than one student's constant negative actions towards another student". These negative actions include physical contact, gestures and mimics and deliberate exclusion from a group. Olweus emphasizes that two equal (physically or psychologically) students' fight or quarrel is not an example of bullying. Smith and Sharp (1994) define bullying as systematic exploitation of force. According to another definition, bullying is a person's or a group of people's saying bad and noxal words repeatedly and upsetting the victim. It can be said that some researchers think that group violence is the heart of school bullying (Pikas, 1975), some think that individual violence is at the forefront (Lowenstein, 1978) and others think that they focus on physical assaults (Arora and Thampson, 1987). Nowadays, the concept of bullying has become broader and now it contains mocking, ridiculing, harassment and isolation (Pişkin, 2002)

Although aggression and bullying have similar effects on people, there are important distinctions between the two. The most significant of them is that there is power imbalance and willingness to hurt the victim repeatedly. In aggression, there is willingness to hurt someone mutually. Also, the person who is bullied cannot defend themselves and does not want to be in a fight in bullying.

It is fundamental not only to define bullying but also to state its type. The most basic distinction is physical bullying and psychological bullying. Physical bullying is hitting, pushing, and kicking someone. Psychological bullying is sometimes referred as social aggression and relational aggression contains verbal abuse, nicknaming, menacing gestures, making malevolent phone calls to the victim's house, hiding private belongings of the victim, isolation and spreading rumors about the victim. Bullying can be constantly hitting or ridiculing the victim, which is direct way of bullying, or it can be 
spreading untrue stories about the victim, which is indirect way of bullying (Rigby et al. 2007). Psychological bullying is thought to be a less serious problem than physical bullying. In a study on teachers' viewpoints of physical, verbal and relational bullying, participants rated relational bullying as less serious compared to other types of bullying. They approached those who were exposed to relational bullying less empathetically and they reported that they did not interfere in most of the cases (Bauman and Del Rio, 2006). Relational bullying is more difficult to observe compared to physical and verbal bullying and this makes it more difficult to identify. Furthermore, the difficulty of identifying relational bullying makes it troublesome to find who does it (Craig et al 2000). With the progression of technology, bullying has started to change shape. Cyber bullying is a kind of psychological bullying which is harming someone deliberately using electronic media such as mobile phones or the Internet. Cyber bullying differs from other types of bullying in many ways. Bully can keep the victim at bay and hide their identity and become anonymous. Moreover, bully can reach large masses and the victim becomes accessible day and night. Cyber bullying is going beyond time limits, physical and personal space.

Bullying students are generally physically strong and have high energy. These kinds of children like exhibiting violent behaviors, going into combat and are proud of being watched by other students while doing these. Bullying children are not completely isolated from their peers but they usually have another group of friends (Olweus, 1993). In Irene and Mona's study (2003) in which they compare female and male students who bully and do not bully, those who bully appeared to have much more unfavorable relationship with their parents. Also, students in this group get angry easily, have difficulty in obeying rules, consider violence as a way of solving their problems and attribute negative features to themselves (Irene and Mona, 2003; Boulton and Smith, 1994; Perren and Alaskart, 2006).

The literature on this issue not only contains the features of bullies but also the negative effects of bullying on the bully which is an anti-social behavior. For instance, from the point of psychological health, bullying kids have depressive symptoms, psychoticism symptoms and suicidal thoughts. Also, bullying has been found to be related to substance abuse, emotional dysregulation and physical health problems.

In a broad study by Pellegrini and Long (2002) on teenagers, it was observed that young males exhibited direct bullying behaviors more and they did it in order to have a social status among their peers. Teenagers may plan their behaviors thinking "If I bully on someone, I can be popular among my peers. So I must do it." or "I would be sad if my friends bullied on me. So I mustn't do it." (Karataş and Öztürk, 2009). Bullying has many reasons and it is claimed that apart from individual features, family and social circle affect showing bullying behaviors (Baldry, 2003).

Type of school attachment and understanding school environment may be a factor in having bullying problems or avoiding them. When school attachment, bully, victim, bully/victim and those who have never been exposed to bullying are compared, those who have never been exposed to bullying have a higher school attachment, prosocial behaviors and beliefs (Cunningham, 2010). In a study on the relationship between bullying and low empathy, male bullying students have insufficient empathy skills and female students who say that they bully have less empathy skills compared to those who say they do not. Moreover, male students who practice more serious bullying types have lower empathy skills and female students who practice indirect bullying have the similar results (Jolliffe and Farrington, 2006). Students mostly explain bullying as "a reaction towards deviation from normal". According to students, the reasons of bullying are deviation from normal in appearance; for instance being ugly, fat, slim, not wearing suitable clothes or wearing weird clothes, wearing eye glasses, skin color or looking weird somehow; deviation from normal in behaviors; for instance talking weirdly, playing with kids from opposite sex, being clumsy or not behaving like peers; deviation from normal in personality; for instance being stupid, childish, weird or insufficiency such as mental retardation, being deaf or being condemned to wheel chair. Apart from that, deviation from normal in relationships is determinant in bullying behaviors (Thornberg, 2010).

Information and research results have been exhibited above. There are thought to be many variables related to bullying and you will find the relationship between parental attitudes and teacher behaviors in this research.

\section{Method}

\subsection{Research Model}

The goal of this research is to present the relationship between "parental attitude and teacher behaviors in predicting school bullying". Therefore, this research has been designed in descriptive relational pattern.

\subsection{Population and Sample}

The population of this study is consisted of all primary school $4^{\text {th }}$ grade students within İstanbul Küçükçekmece Municipality borders. Data were gathered from lower, mid and upper socio-economic level schools (2 schools on each level, 6 schools in total.) 702 volunteer students constitute the sample of this research. 363 (52\%) of these students are female students and 338 (48\%) of the students are male students. 


\subsection{Data Collection Tools}

\subsubsection{Tendency for Bullying Scale}

It was developed by Dölek (2002) and has been used to determine students' bullying tendency. This scale has 26 items and $6 \mathrm{sub}$ dimensions. These sub dimensions are negative reflection (5 items), insufficiency of emotional sharing (6 items), assuming themselves right ( 4 items), upsetting others ( 4 items), using force ( 6 items) and not being disturbed (2 items). Cronbach Alfa Coefficient for the internal consistency reliability of the scale is ,67 and Cronbach Alfa Coefficient of all sub tests are over ,50. One way t-test was calculated between upper and lower quartiles and all dimensions between students on upper and lower quartiles were found to be distinctive. Scale was applied to 24 people in 2 weeks in order to determine test-retest reliability and Pearson product-moment correlation coefficient was found between the two applications. Scale in total and sub dimensions except for insufficiency of emotional sharing, upsetting others and using force sub dimensions were found to be reliable. Cronbach alfa coefficients of each sub scale were calculated and they were found to vary between .78 and .82 .

\subsubsection{Parental Attitude Scale}

Parental Attitude Scale which was developed by Kuzgun and Eldeleklioğlu (1999) was used to measure students' perception of their parents' attitudes. In order to determine the reliability of the scale, internal consistency coefficients of sub scales in the scale was calculated. Internal consistency coefficient for democratic attitude is .89 , for protectivedemanding attitude it is .82 , for authoritarian attitude it is .78 (Kuzgun and Eldeleklioğlu 1999). Cronbach Alfa coefficients of this scale were calculated separately for this research. Cronbach Alfa coefficient of paternal attitude is .77 and that of maternal attitude is .80 .

\subsubsection{Perceived Teacher Behavior Scale}

Perceived Teacher Behavior Scale was developed by Erdoğdu in order to present how primary school students perceive their teachers' behavior (democratic-authoritarian) in and out of the classroom. Scale is consisted of 29 items. Test-retest reliability coefficient (.70), split half reliability coefficient (.79) and Cronbach Alfa coefficients (.75) were calculated in order to find out the reliability of the scale. The results obtained show that the coefficients are high. The distinctiveness value which was found via item analysis is rjx:.38. As a result of factor analysis to study the validity of the scale it was found that the scale is consisted of two factors (Erdoğdu, 2005). Cronbach coefficient was calculated for this study and it was found to be .84 .

\subsection{Data Analysis}

T-test was used for the significance between two variables and one way analysis of variance (ANOVA) was used for the significance of more than two variables. Multiple regression analysis was used to present parental attitude and teacher behaviors in predicting bullying.

\section{Findings}

Table 1. Descriptive Statistics of Bullying Scale

\begin{tabular}{llll}
\hline Scales & $\overline{\mathbf{X}}$ & $\mathbf{S}$ \\
\hline $\begin{array}{l}\text { Negative reflection } \\
\text { Insufficiency of } \quad \text { emotional }\end{array}$ & 8.57 & 3.64 \\
sharing & 10.67 & 3.93 \\
Assuming themselves right & 8.37 & \\
Upsetting others & 6.46 & 2.93 \\
Using force & 10.32 & 2.53 \\
Being disturbed & 2.05 & 3.98 \\
\hline Bullying (Total) & 46.55 & 1.15 \\
\hline
\end{tabular}

The arithmetic average of bullying sub scales varies between 2.05 and 10.67. Arithmetic average of total points on scale is 46.55 . The scale is a four point likert scale. As the rate of average and the number of items gets closer to four, it means that bullying tendency increases. As it gets closer to zero, it means that bullying tendency decreases. In this context, the rate of bullying scale arithmetic average and total item number is 1.79 . Students volunteered in this research have been found to have a low bullying tendency. The highest rate among subscales is "assuming themselves right" (2.09). 
Table 2. The Results of t-Test According to Gender and Points on Bullying Scale

\begin{tabular}{lllllll}
\hline Variables & & $\mathbf{N}$ & $\overline{\mathbf{X}} \pm \mathbf{S}$ & $\mathbf{d f}$ & $\boldsymbol{t}$ & $\boldsymbol{p}$ \\
\hline \multirow{3}{*}{ Gender } & Female & 364 & $44.34 \pm 12.06$ & 700 & 4.74 & .000 \\
& Male & 338 & $48.94 \pm 13.60$ & & & \\
\hline
\end{tabular}

Students' points on bullying scale have significant distinctions according to gender [ $\mathrm{t}(700)=4.74, \mathrm{p}<.01]$. According to this, male students' point on bullying scale $(\bar{x}=48.94)$, is higher than that of female students $(\bar{x}=44.34)$. In other words, male students have a higher bullying tendency.

There is no significant distinction between whether students' parents live together or not or whether they are alive or not.

Table 3 presents the result of one way analysis of variance according to success, participation in cultural activities, age and points on bullying scale.

Table 3. The Result of One Way Analysis of Variance of Bullying Scale Points According to Some Variables

\begin{tabular}{|c|c|c|c|c|c|c|c|c|c|}
\hline \multicolumn{2}{|l|}{ Variables } & \multirow{2}{*}{$\begin{array}{l}\mathbf{N} \\
272\end{array}$} & \multirow{2}{*}{$\begin{array}{l}\overline{\mathbf{X}} \pm \mathbf{S} \\
44.94 \pm 13.09\end{array}$} & \multirow{2}{*}{$\begin{array}{l}\begin{array}{l}\text { Source of } \\
\text { Variance }\end{array} \\
\text { Betweengroups } \\
\end{array}$} & \multirow{2}{*}{$\begin{array}{l}\begin{array}{l}\text { Sum of } \\
\text { Squares }\end{array} \\
1560.58\end{array}$} & \multirow{2}{*}{$\begin{array}{l}\text { df } \\
3\end{array}$} & \multirow{2}{*}{$\begin{array}{l}\begin{array}{l}\text { Average } \\
\text { of } \\
\text { Squares }\end{array} \\
520.19 \\
\end{array}$} & \multirow[t]{2}{*}{$\mathbf{F}$} & \multirow[t]{2}{*}{$\mathbf{p}$} \\
\hline & 9 & & & & & & & & \\
\hline & 10 & 295 & $47.29 \pm 13.01$ & Withingroups & 117228.40 & 698 & & 3.09 & .026 \\
\hline & 11 & 82 & $50.65 \pm 11.30$ & & & & 167.94 & & \\
\hline 萬 & $\begin{array}{ll}12 & \text { and } \\
\text { above } & \end{array}$ & 53 & $52.33 \pm 8.05$ & Total & 118788.98 & 701 & & & \\
\hline \multirow{3}{*}{ 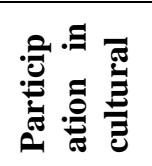 } & Yes & 461 & $45.65 \pm 13.57$ & Betweengroups & 2716.18 & 2 & 1358.08 & & \\
\hline & Sometimes & 121 & $45.69 \pm 11.44$ & Withingroups & 116072.81 & 699 & 166.05 & 8.179 & .000 \\
\hline & No & 120 & $50.89 \pm 11.42$ & Total & 118788.98 & 701 & & & \\
\hline \multirow{3}{*}{$\begin{array}{l}\mathscr{n} \\
\stackrel{\mathscr{E}}{\mathscr{E}} \\
\tilde{E}\end{array}$} & Mediocre & 63 & $54.04 \pm 11.36$ & Betweengroups & 8703.72 & 2 & 4351.86 & & \\
\hline & Good & 183 & $50.15 \pm 12.78$ & Withingroups & 110085.25 & 699 & 157.49 & 27.63 & .000 \\
\hline & Very good & 456 & $44.08 \pm 12.61$ & Total & 118788.98 & 701 & & & \\
\hline
\end{tabular}

According to analysis results, students' points on bullying scale have significant distinctions according to age [f (3-698) $=3.09, \mathrm{p}<.05]$. According to this, students' points on bullying scale increase as their ages increase too. Scheffe test was used to see if there is a significant variance between the groups. However, it has found that there is no significant variance between the groups.

According to analysis results, students' points on bullying scale have significant distinctions according to their participation in cultural activities [f $(2-699)=8.179, \mathrm{p}<.01]$. According to this, students who participate in cultural activities have lower points on bullying scale compared to those who do not participate in such events. Scheffe test was used to see if there is a significant variance between the groups. The variance between groups is significant for those who said "yes" as an answer. In other words, students who take part in cultural activities have lower bullying tendency.

According to analysis results, students' points on bullying scale have significant distinctions according to success [f $(2-699)=27.63, \mathrm{p}<.01]$. According to this, students are very good at school have lower points on bullying scale compared to those are good and mediocre at school. Scheffe test was used to see if there is a significant variance between the groups. The variance between groups is significant for those who get A on exams. According to this finding, students who ace on their exams have lower bullying tendency compared to good or mediocre students.

There is no significant distinction between whether students participate in sportive events, their siblings, the education level of parents and their level of income. 
Table 4. The Result of Multiple Regression Analysis in Predicting Bullying

\begin{tabular}{lccccc}
\hline Variable & \multicolumn{3}{c}{ Standard } \\
E & Error & Beta & $\mathrm{t}$ & $\mathrm{p}$ \\
\hline Constant & 6.47 & 2.74 & & 2.36 & .018 \\
Maternal Attitude & .149 & .028 & .241 & 5.27 & .000 \\
Paternal Attitude & .060 & .026 & .101 & 2.27 & .023 \\
Teacher Behaviors & .446 & .062 & .267 & 7.18 & .000 \\
\hline $\mathrm{R}=0.50 \mathrm{R}^{2}=0.25$ & & & & & \\
$\mathrm{~F}(3,697)=78.27 \mathrm{P}=.000$ & & & & \\
\hline
\end{tabular}

Table 4 demonstrated that, authoritarian attitudes of mothers, fathers and teachers $\left(\mathrm{R}=.50, \mathrm{R}^{2}=.25, \mathrm{p}<.01\right)$ have predicted significantly to students' bullying problem. These three variables explain only $25 \%$ of variance.

According to standardized regression coefficient ( $(3)$, predictor variable's comparative order of importance of bullying is teachers' authoritarian behaviors and parental authoritarian behaviors. When t-test results on significance of regression coefficients are examined, parental authoritarian behaviors are significantly predictive on bullying.

Table 5. Multiple Regression Analysis Results on Predicting Bullying

\begin{tabular}{|c|c|c|c|c|c|}
\hline Variables & $\mathbf{B}$ & $\begin{array}{l}\text { Standa } \\
\text { Error }\end{array}$ & Beta & $\mathbf{t}$ & $\mathbf{p}$ \\
\hline Constant & .453 & .253 & & 8.79 & .000 \\
\hline Negative Reflection & .978 & .025 & .273 & 39.09 & .000 \\
\hline $\begin{array}{l}\text { Insufficiency of } \quad \text { Emotional } \\
\text { Sharing }\end{array}$ & 1.002 & .018 & .303 & 55.92 & .000 \\
\hline Assuming Themselves Right & .929 & .027 & .210 & 34.39 & .000 \\
\hline Upsetting Others & 1.112 & .033 & .216 & 33.87 & .000 \\
\hline Using force & .962 & .026 & .294 & 37.34 & .000 \\
\hline Not Being Disturbed & 1.033 & .055 & .092 & 18.74 & .000 \\
\hline \multicolumn{6}{|l|}{$R=0.99 R^{2}=0.98$} \\
\hline$F(6,693)=7403.36 P=.000$ & & & & & \\
\hline
\end{tabular}

Table 5 demonstrated that, negative reflection, emotional regression, assuming themselves right, upsetting others, using force and not being disturbed $\left(\mathrm{R}=0.99, \mathrm{R}^{2}=0.98, \mathrm{p}<0.01\right)$. have predicted significantly to students' bullying problem. These six variables explain $98 \%$ of variance.

According to standardized regression coefficient ( $(3)$, predictor variable's comparative order of importance of bullying is emotional sharing, using force, negative reflection, upsetting others, assuming themselves right and not being disturbed. When t-test results on significance of regression coefficients are examined, all these six variables are significantly predictive on bullying.

\section{Conclusion and Discussion}

According to research findings, male students have a higher tendency to bullying than female students. Main reasons to this are male students' efforts to subordinate others, trying to look stronger than others and their being more difficult to be under control and discipline. Research on this topic shows that both bullies and victims are mostly male students (Pişkin, 2002; Güvenilir, 2008; Olweus, 2003; Rigby, 2004; Juvonen, Adrienne and Graham, 2000; Özen, 2006; Yurtal and Cenkseven, 2005; Perry, Perry and Weiss, 1989). Research by Pekel and Uçanok (2005) states that females are the target of mockery, relational aggression and males display behaviors of threatening / intimidation, mockery, direct and relational aggression.

It is stated in a study by Crick, Casas and Mosher (1997) and Archer (2004) that females use indirect aggression words more than males and these words are mostly used around the age of 11, but this behavior starts to decrease during puberty. It is, also, in this study that females' aggressive behaviors are mostly relational aggression and males' aggressive behaviors are mostly verbal and physical aggression. Craig (1998) suggests that males' aggressive behaviors decrease as they get older, but their verbal aggressive behaviors increase. Furthermore, male bullies use physical 
aggressive behaviors at first then they use both verbal and physical aggressive behaviors. Mynard and Joseph (2000) claim that males are usually exposed to physical aggression and aggression towards their personal belongings; whereas, females are usually exposed to relational aggression and there is no significance between males and females in terms of being exposed to verbal aggression.

As students get older, their tendency to bully on someone increases. Students' tendency to show their strength increases, they want to be approved and subordinate their friends, they want to form a social circle and want to be the leader especially when they get older. All these and factors like physical and psychological collapse during puberty may lead to bullying.

According to a study, bullying decreases as people get older. Especially physical bullying occurs more often ages 6-9 and as children get older, their tendency to bullying decreases. Psychological bullying is mostly seen ages 6-9, between ages 10-13 it is seen in both genders and between ages 14-17 it decreases (Finkelhor, Ormrod, Turner; 2009).

It is reported in a study by Scheithauer, Hayer, Petermann and Jugert (2006) that students from lower grades are exposed to bullying more. In other words, students from lower grades are exposed to bullying almost as twice as students from upper grades are exposed to it. Physical bullying is ascertained to decrease after $8^{\text {th }}$ grade, but verbal and relational bullying increases until $9^{\text {th }}$ grade. Consequently, physical bullying increases until secondary school and decreases later; however, verbal and relational bullying increase with age. Baldry and Farrington (2000) state that being exposed to bullying decreases with age; whereas, bullying behavior is not affected by age. In a study by Craig (1998) in which the aim was to find the gender and class distinctions between bully, victim, bully/victim and control group in terms of physical, verbal and relational bullying, while there is a decrease in physical bullying with age, there is an increase in verbal bullying, but there is no change for relational bullying. In a study by Dölek (2002), it has been found that one fifth of students are exposed to bullying from students in their own class or students from different classes at their age and lastly students from upper grades. In a study by Frisen et al. (2007) which aimed to identify teenagers' experience and perception about bullying, participants said that ages 7-9 were the ages they were exposed to bullying most; bullies said that they exhibited bullying behavior most at ages 10,11 and 12 .

There are distinctions between students' participation in cultural activities and bullying. According to this, students who do not attend cultural activities have more tendency to bullying than students who attend cultural activities. Students' participation in such activities enables them to direct their energy and attention to them and to get social support from their friends. These activities enable them also to enhance their intellectual development. All these retain them from bullying. There is no finding on relationship between participating in cultural activities and bullying tendency. Apart from that, Houbre et al. (2006) found that both bullies and victims had low self-concept almost in all fields. Victimized students evaluated themselves far lower compared to other groups in terms of social abilities, physical appearance, self-esteem and athletic abilities. In this context, participation in cultural activities enhances students' self-esteem and social abilities; therefore, these students have lower bullying tendency.

Students who ace in their exams have lower bullying tendency compared to unsuccessful students. Unsuccessful students try to minimize their failure by subordinating their peers to be approved by their classmates. Since such students do not have goals to shape their future, they have bullying tendency.

In a study by Maye et al. (2009), it has been found that bullying causes negative effects on victimized students' academic success. In a study on academic success of bullies and victims, bullying predicts low academic success. Apart from that, being victim causes low academic success, too. Research on this topic shows that victims rather than bullies have usually been the center of such research and victims' academic success has usually been found to be low (Kochenderfer ve Ladd,1996; Mynard ve Joseph, 1997; Bush ve Ladd, 2000; Austin ve Joseph, 1996; Schwartz, 2000).

According to research findings, students who consider their teachers as authoritarian have more bullying tendency compared to those who consider their mothers and fathers (respectively) as authoritarian. There may be many reasons to it. Students' generally spending more time with their teacher and mothers than their fathers may be the reason. Apart from that, teachers' authoritarian behaviors put students behind eight ball and students take teachers as example. These factors are thought to lead students to bullying.

In a study by Oliver, Oaks and Hoover (1994), it has been found that bullies' families are distant to their kids, there are no intrafamilial dynamics, they are incoherent in their relationships, tolerant to their kids' violent behaviors, there is familial dissonance and they raise their kids reinforcing their bullying behaviors. Amodei and Scott (2002) have found out that the most important environmental factor in bullying behaviors is family. Negative relations in the family have negative effects on children and these negative effects have an important role on children's violent behaviors. According to Mazefsky and Farrel (2005), the basic emotional attitude of kids' caretaker in their early times (generally their mothers) is significant. Children who grow up with negative emotional attitude which is characterized by lack of warmth, attention and attachment and insufficient familial support cannot deal properly with violence when they are 
exposed to it. Hence, they may develop violent behaviors. Bullies have a more authoritarian family structure compared to others, they have nonsustaining and punisher parents and they usually argue with their parents especially with their mothers (Baldry and Farrington, 2000). When we take a look at bullies' mothers, we can see that they are lack of empathy, they use strict discipline methods and they do not enable their kids to express themselves emotionally (Curtner-Smith et al 2006). Factors like compeller parental attitudes, familial hostility, lack of warmth and harmony in the family, marital conflict, being tolerant to kids' violent behaviors and physical violence are found in relation with bullying behaviors (Bowers et al. 1992). According to Baldry (2003), domestic violence has negative effects on children's behaviors. Being exposed to domestic violence is related to bullying and being exposed to bullying. According to this, a kid who is reared with domestic violence will do it to their friends in the future.

Subscales which predict bullying most is insufficient emotional sharing, using force and negative reflection. Students with bullying tendency remain insensitive to their friends' feelings, have low empathy skills and have difficulty in calming themselves down. In addition, bullies have sense of self based on power, regard themselves as strict, successful and skillful, do not regard themselves as dissatisfied; hence, they tend to use force. Finally, students make negative reflections to weaker students because they direct emotions which make them feel bad like anger, frustration and anxiety.

Awareness studies about bullying and negative effects of bullying should be made in schools especially in those where there is bullying. According to research findings, teachers' authoritarian attitudes are more related to bullying behaviors than those of parents'. In this context, teachers who are perceived as authoritarian by students should be identified and they should be given seminars on class discipline, effective and healthy communication skills.

According to research findings, bullying tendency increases with age. As teenagers are a risk group, these students should be given seminars on friend relationships and empathy skills.

Students' participation in socio-cultural activities lowers bullying tendency. In this context, there should be more socio-cultural activities and risky students should be directed to such activities.

By preventing bullying; there will be good peer relations. Conditions both for bullies and for victims in and out of school should be healed; therefore, victims will perceive school environment as secure. Studies on enabling victims to gain self-confidence and make one or two close friends should be organized. For bullies, there should be studies to help them choose a socially approved way in which they can express themselves well instead of using violence.

\section{References}

Amodei, N., \& Scott, A. A. (2002). Psychologists contribution to the prevention of youth violence. The Social Science Journal, 39, 511-526. http://dx.doi.org/10.1016/S0362-3319(02)00226-4

Archer, J. (2004). Sex differences in aggression in real world settings: A meta-analytic review. Review of General Psychology, 8, 291-322. http://dx.doi.org/10.1037/1089-2680.8.4.291

Arora, C. M., \& Thompson, D. A. (1987). Defining bullying for a secondary school. Education and Child Psychology, 4, $110-120$.

Austin, S., \& Joseph, S. (1996). Assessment of bully/victim problems in 8 to 11 year olds. British Journal of Educational Psychology, 66(4), 447-456. http://dx.doi.org/10.1111/j.2044-8279.1996.tb01211.x

Baldry, A. C., \& Farrington, D. P. (2000). Bullies and delinquets: personal characteristics and parental style. Journal of Community and Applied Social Psychology, 10, 17-31. http://dx.doi.org/10.1002/(SICI)1099-1298(200001/02)10:1<17::AID-CASP526>3.0.CO;2-M

Baldry, A. C. (2003). Bullying in schools and exposure to domestic violence. Child Abuse and Neglect, 27, 713-732. http://dx.doi.org/10.1016/S0145-2134(03)00114-5

Bauman, S., \& Del Rio, A. (2009). Preservice teachers' responses to bullying: comparing physical, verbal and relational bullying. Journal of Educational Psychology, 98(1), 219-231. http://dx.doi.org/10.1037/0022-0663.98.1.219

Bowers, L, Smith, P. K., \& Binney, V. (1992). Cohesion and power in the families of children involved in bully/victim problems at school. Journal of Family Therapy, 14, 371-387. http://dx.doi.org/10.1046/j..1992.00467.x

Boulton, M. J., \& Smith, P. K. (1994). Bully/victim problems in middle school children: stability, self-perceived competence, peer perceptions and peer acceptance. British Journal of Educational Psychology, 12, 315-329. http://dx.doi.org/10.1111/j.2044-835x.1994.tb00637.x

Bush, E. S., \& Ladd, G. W. (2001). Peer rejection as an antecedent of young children's school adjusment: An examination of mediating processes. Development Psychology, 37, 550-560. http://dx.doi.org/10.1037/0012-1649.37.4.550 
Craig, W. M. (1998). The relationship among bullying, victimization, depression, anxiety, and agression in elementary school children. Personal and Individual Differences, 24(1), 123-130. http://dx.doi.org/10.1016/S0191-8869(97)00145-1

Craig, W., Henderson, K., \& Murphy, J. G. (2000). Prospective teacher's attitudes toward bullying and victimization. School Psychology International, 21(1), 5-21. http://dx.doi.org/10.1177/0143034300211001

Crick, N. R., Casas, J. F., \& Mosher, M. (1997). Relational and overt aggression in preschool. Developmental Psychology, 33, 579-588. http://dx.doi.org/10.1037/0012-1649.33.4.579

Cunningham, N. J. (2007). Level of bonding to school and perception of the school environment by bullies, victims, and bully victims. Journal of Early Adolescence, 27(4), 457-478. http://dx.doi.org/10.1177/0272431607302940

Curtner-Smith M. E., Culp, A. M., Culp, R., Scheib, C., Owen, K., Tilley, A., Murphy, M., Parkman, K. O., \& Coleman, P. W. (2006). Mothers' parenting and young economically disadvantaged children's relational and overt bullying. Journal of Child and Family Studies, 15(2), 181-193. http://dx.doi.org/10.1007/s10826-005-9016-7

Dölek, N. (2002). “Öğrencilerde zorbaca davranışların araştırılması ve önleyici bir program modeli”. Marmara Üniversitesi Sosyal Bilimler Enstitüsü (Yayınlanmamış Doktora Tezi).

Erdoğdu, M. Y. (2013). Algılanan öğretmen davranışları ölçeğinin. geliştirilmesi. İnönü Üniversitesi Sosyal Bilimler Dergisi. 14(1), 115-128.

Finkelhor, D., Ormrod, R. K., \& Turner H. A. (2009). The developmental epidemiology of childhood victimization. Journal of Interpersonal Violence, 24(5), 711-731. http://dx.doi.org/10.1177/0886260508317185

Frisen, A., Jonsson, A., \& Persson, C. (2007) Adolescent's Perception of Bullying: Who is the Victim? Who is the Bully What Can Be Done to Stop Bullying. Adolesscence, 42(168), 749-761.

Güvenir, T. (2008) Okulda Akran istismarı. Kök Yayıncılık, Ankara.

Houbre, B., Tarquinio, C., Thuillier, I., \& Hergott, E. (2006). Bullying among students and its consequences on health. European Journal of Psychology of Education, 2,183-208. http://dx.doi.org/10.1007/BF03173576

Irene, C., \& Mona, M. (2003). Personality and family relations of children who bully. Personality and Individual Differences, 35, 559-567. http://dx.doi.org/10.1016/S0191-8869(02)00218-0

Jolliffe, D., \& Farrington, D. P. (2006). Examining the relationship between low empathy and bullying. Aggressive behavior, 32, 540-550. http://dx.doi.org/10.1002/ab.20154

Juvonen, J., Adrienne, N., \& Graham, S. (2001). Peer harrassment, psychological adjustment, and school functioning in early adolescence. Journal of Educational Psychology, 92(2), 349-359.

http://dx.doi.org/10.1037/0022-0663.92.2.349

Lowenstein, L. (1978). Who is the bully? Bulletin of the British Psychological Society, 31, 147-149.

Karataş, H., \& Öztürk, C. (2009). Sosyal bilişsel teori ile zorbalığa yaklaşım. Dokuz Eylül Üniversitesi Hemşirelik Yüksekokulu Elektronik Dergisi, 2(2), 61-74.

Kochenderfer, B. J., \& Ladd, G. W. (1996). Peer victimization. Cause or consequence of school maladjustment? Child Development, 67, 710-722. http://dx.doi.org/10.2307/1131701

Kuzgun, Y., \& Eldeleklioğlu, J. (2005). Ana Baba Tutumları Ölçeği (Ergenler ve yetişkinler için). PDR'de kullanılan Ölçekler: Rehberlik Ve Psikolojik Danışmada Kullanılan Ölçme Araçları Ve Programları Dizisi 1 (Editörler: Kuzgun, Y. Bacanl1, F.). Ankara: Nobel Yayınları.

Mazefsky, C. A., \& Farrell, A. D. (2005). The role of witnessing violence, peer provocation, family support, and parenting practices in the aggressive behavior of rural adolescents. Journal of Child and Family Studies, 14(1), 7185. http://dx.doi.org/10.1007/s10826-005-1115-y

Mynard, H., \& Joseph, S. (1997). Bully/victim problems and their association with eysenck's personality dimensions in 8 to 13 year-olds. British Journal of Educational Psychology, 67(1), 51-54. http://dx.doi.org/10.1111/j.2044-8279.1997.tb01226.x

Mynard, H., \& Joseph, S. (2000). Development of the multidimensional peer-victimization scale. Aggressive Behavior, 26(20) 169-178. http://dx.doi.org/10.1002/(SICI)1098-2337(2000)26:2<169::AID-AB3>3.0.CO;2-A

Oliver, R., Oaks I. N., \& Hoover, J. H. (1994). Family issues and interventions in bully and victim relationships. School Counselor, 41(3), 1999-2003.

Olweus, D. (2003). Bullying at school. Blackwell Publishing, Oxford, United Kingdom 
Olweus, D. (1973). Hackkycklingar och Oversittare. Forskning om skolmobbning (Victims and bullies: Research on school bullying). Stockholm: Almqvist ve Wicksell.

Olweus, D. (1978). Aggression in the Schools: Bullies and Whipping Boys. Washington, DC: Hemisphere (Wiley).

Olweus, D. (1993). Bullying at school: What we know and what we can do. Oxford: Blackwell Publishers.

Özen, D. Ş. (2006). Akran zorbalığına maruz kalmanın olası yordayıcıları ve cinsiyet ile yaşa bağlı değişimi. 1.Şiddet ve Okul Seтроzуити: Bildiri Özetleri, (33), İstanbul.

Pellegrini, A. D., \& Long, J. D. (2002). A Longitudinal Study Of Bullying, Dominance, And Victimization During The Transition From Primary School Through Middle School. British Journal of Developmental Psychology, 20, 259-280. http://dx.doi.org/10.1348/026151002166442

Perren, S., \& Alaskart, F. D. (2006). Social behavior and peer relationships of victims, bully-victims and bullies in kindergarden. Journal of Child Psychology and Psychiatry, 47(1), 45-57. http://dx.doi.org/10.1111/j.1469-7610.2005.01445.x

Perry, D. G., Perry, L. C., \& Weiss, R. J. (1989). Sex differences in the consequences that children anticipate for aggression. Developmental Psychology, 25, 312-319. http://dx.doi.org/10.1037/0012-1649.25.2.312

Pikas, A. (1975). How to Stop Peer Bullying. Stockholm: AMA Service.

Pişkin, M. (2002). Okul zorbalığı, tanımı, türleri, ilişkili olduğu faktörler ve alınabilecek önlemler. Kuram ve Uygulamada Ĕ̈itim Bilimleri, 2, 531-562.

Rigby, K. (2004). Why do somechildren bullly at school? The contributions of negative attitudes towards victims and the perceived expectations of friends, parents and teachers. Social Psychology International, 25, 287-300. http://dx.doi.org/10.1177/0143034304046902

Rigby, K., Slee, P. T., \& Martin, G. (2007). Implications of inadequate parental bonding and peer victimization for adolescent mental heath. Journal of Adolescence of Mental Health, 2, 1-3.

Schwartz, D. (2000). Subtypes of victims and aggressors in children's peer groups.Journal of Abnormal Child Psychology, 28(2), 181-192. http://dx.doi.org/10.1023/A:1005174831561

Scheithauer, H., Hayer, T., Petermann, F., \& Jugert, G. (2006). Physical, verbal and relational forms of bullying among German students: age trends, gender differences, and correlates. Aggressive Behavior, 32, 261-275. http://dx.doi.org/10.1002/ab.20128

Smith, P. K., \& Sharp, S. (1994). School bullying. London: Routledge. http://dx.doi.org/10.4324/9780203425497

Thornberg, R. (2010). School children's social representations on bullying causes. Psychology in the schools, 47(4), 311-327.

Yurtal, F., \& Cenkseven, F. (2005). İlköğretim okullarında zorbalığın incelenmesi 1. Şiddet Ve Okul: Okul Ve Çevresinde Çocuğa Yönelik Şiddet Ve Alınabilecek Tedbirler Uluslararası Katılımlı Sempozyumu. (14), İstanbul.

Wolke, D., Woods, S., Stanford, K., \& Schulz, H. (2001). Bullying and Victimization of Primary School Children In England and Germany: Prevalence And School Factors. British Journal of Psychology, 92, 673-696. http://dx.doi.org/10.1348/000712601162419 